\title{
New Insights and Advances in Pathogenesis and Treatment of Very Early Onset Inflammatory Bowel Disease
}

\author{
Qi-Qi Li ${ }^{1+}$, Hui-Hong Zhang ${ }^{1 \dagger}$ and Shi-Xue Dai ${ }^{1,2,3 *}$ \\ ${ }^{1}$ The Second School of Clinical Medicine, Southern Medical University, Guangzhou, China, ${ }^{2}$ Department of Gastroenterology, \\ Guangdong Provincial Geriatrics Institute, National Key Clinical Specialty, Guangdong Provincial People's Hospital, \\ Guangdong Academy of Medical Sciences, Guangzhou, China, ${ }^{3}$ Department of Gastroenterology, Guangdong Provincial \\ People's Hospital, Guangdong Academy of Medical Sciences, South China University of Technology, Guangzhou, China
}

OPEN ACCESS

Edited by:

Séamus Hussey,

National Children's Research Centre

(NCRC), Ireland

Reviewed by:

Ruggiero Francavilla,

University of Bari Aldo Moro, Italy

Corentin Babakissa,

Université de Sherbrooke, Canada

*Correspondence:

Shi-Xue Dai

daishixue@gdph.org.cn;

shixuedai@hotmail.com

tThese authors have contributed equally to this work and share first authorship

Specialty section:

This article was submitted to

Pediatric Gastroenterology,

Hepatology and Nutrition,

a section of the journal

Frontiers in Pediatrics

Received: 24 May 2021

Accepted: 25 January 2022

Published: 01 March 2022

Citation:

Li Q-Q, Zhang H-H and Dai S-X (2022) New Insights and Advances in Pathogenesis and Treatment of Very

Early Onset Inflammatory Bowel

Disease. Front. Pediatr. 10:714054

doi: 10.3389/fped.2022.714054
Very early onset inflammatory bowel disease (VEO-IBD) is characterized by multifactorial chronic recurrent intestinal inflammation. Compared with elderly patients, those with VEO-IBD have a more serious condition, not responsive to conventional treatments, with a poor prognosis. Recent studies found that genetic and immunologic abnormalities are closely related to VEO-IBD. Intestinal immune homeostasis monogenic defects (IIHMDs) are changed through various mechanisms. Recent studies have also revealed that abnormalities in genes and immune molecular mechanisms are closely related to VEO-IBD. IIHMDs change through various mechanisms. Epigenetic factors can mediate the interaction between the environment and genome, and genetic factors and immune molecules may be involved in the pathogenesis of the environment and gut microbiota. These discoveries will provide new directions and ideas for the treatment of VEO-IBD.

Keywords: microRNA, circular RNA, biologics, immunity, gut microbiota

\section{INTRODUCTION}

Very early onset inflammatory bowel disease (VEO-IBD) refers to a subgroup of pediatric patients diagnosed with IBD before the age of 6 years (1); it includes subclasses of infantIBD and neonatal IBD diagnosed before the age of 2 years and 28 days, respectively. Epidemiological data show that the incidence of VEO-IBD has been increasing rapidly, and one study showed that the incidence had reached $7.2 \%$ (2). The increasing incidence of VEO-IBD suggests that it is urgent to understand its pathogenesis. The latest and largest genetic association study collected genomewide association data for over 75,000 patients and controls and identified 163 susceptibility loci for IBD. Interestingly, twin and family studies of IBD showed that for a child with an affected sibling, the risk increases 26 times for Crohn's disease (CD) and increases 9 times for ulcerative colitis (UC). This suggests that both genetic and environmental factors may affect the pathogenesis of VEO-IBD. However, the pathogenesis of VEO-IBD is still not fully clear. To help solve the existing problems, this narrative review starts from the genetic pathogenesis of VEO-IBD, systematically and comprehensively summarizes the existing pathogenesis and treatment, and provides a potential breakthrough point for the therapeutics of VEO-IBD. 


\section{GENETIC FACTORS}

\section{Gene Abnormalities}

Owing to technological progress in genetic testing and DNA sequencing, many genome-wide association studies (GWAS) have been improved, showing new single nucleotide polymorphisms (SNPs) (3). However, the explainable susceptibility loci and genetic risk factors discovered thus far only account for $20-25 \%$ of the heritability (genetic risk) (4). Moreover, monogenic mutations have been found mostly in children aged under 6 years, and most conventional polygenic IBD patients are older than 7 years.

Discovered in 2001, nucleotide-binding oligomerization domain containing 2 (NOD2) was the first susceptibility gene for CD. It encodes a protein that acts as an intracellular receptor for bacterial products in monocytes and transduces signals activating NFKB. Polymorphisms in NOD2 are one of the greatest genetic risk factors for Crohn's disease. Three different non-synonomous NOD2 polymorphisms, R702 W, G908R, and L1007fsincC, account for $\sim 80 \%$ of all NOD2-associated cases of Crohn's disease and they have been reported to cause a loss of receptor function in response to muramyl dipeptide (MDP) stimulation (5). It has been shown that the perception of NOD protein on bacteria is associated with the induction of autophagy (6). DCs from CD patients with susceptibility variants in the NOD2 gene are deficient in autophagy induction, and the localization of bacteria in autophagolysosomes is reduced (7). Additionally, the genome map of CD patients shows that NOD2 deficiency and mutationsare related to CD in the ileum. Therefore, the interaction between ileal microflora and mucosal immunity is changed by NOD2 mutation, which is a highrisk factor for multiple complications of ileal $\mathrm{CD}$ and indicates increased susceptibility to CD.

\section{miRNA Abnormalities}

$\mathrm{CD}$ and UC have differences not only in the tissue miRNA spectrum but also in the peripheral blood miRNA spectrum. Recently, several studies have analyzed the differential expression of miRNAs in tissue samples and blood between IBD patients and healthy controls, showing that miRNAs may be regarded as novel biomarkers of these diseases (8). Therefore, the recognition of different miRNA expression profiles may provide a method to determine the course of the disease at an early stage.

Serum miR-146a and miR-146b decrease with IFX treatment and long-term glucocorticoid (GC) treatment (weeks) but not with short-term GC treatment (days) (9). Previous studies have shown that miR-146a and miR-146b are responsive to endotoxin, while increasing miR-146a or miR-146b is dependent on inflammatory stimuli (10). miR-146b was previously described as a monitoring biomarker for IBD, positively correlated with endoscopic disease activity, and more specific than serum creactive protein (9). In this study, serum miR-320a was found to decrease in response to both infliximab (IFX) treatment and longterm steroids (weeks) but not to decrease during shorter courses of GC treatment. In the resting colonic mucosa of patients with $\mathrm{UC}$ and $\mathrm{CD}$, the levels of miRNA miR-320a were higher than those in controls, which may be caused by the sensitivity of the resting colonic mucosa to environmental factors (11).

Normally, miRNA miR-126 decreases with anti-TNF- $\alpha$ and shows a decreasing trend with GCs. A previous study also showed that miR-126 expression is higher in IBD biopsies than in controls and in vitro, and overexpression of miR-126 leads to intestinal mucosal barrier dysfunction (12). After the miRNA differential expression changes are confirmed, miRNA may also become a target of future treatment.

\section{Circular RNAs}

Non-coding RNAs (ncRNAs), circular RNAs (circRNAs) produced by reverse splicing of exons from precursor mRNAs, are ncRNAs that mainly act as elements of regulation. Increasing evidence has shown that cyclic RNAs can regulate gene expression through adsorption of miRNAs or interactions with other molecules at the transcriptional or posttranscriptional level. Furthermore, the evolutionary conservation of cyclic RNAs and their specific loop structure formed by phosphodiesters ' 5 to 3 ' leads to their resistance tonucleic acid exonucleases, causing a relatively stable expression in the cytoplasm. These features suggest that cyclic RNAs may be ideal biomarkers.

Several studies have shown that circRNA expression dysregulation plays a role in the progression of some cancers and some specific autoimmune diseases (13). CircRNA-004662 has been found to be a better and possible diagnostic biomarker for $\mathrm{CD}$ in terms of IBD pathogenesis and it may be a new candidate gene to differentiate CD from UC (14). It has also been found that circRNA-103765 in peripheral blood mono-nuclear cells (PBMCs) of patients with active IBD is significantly upregulated, and IFX treatment can significantly reverse circRNA-103765 expression. In vitro studies have shown that TNF- $\alpha$ induces circRNA-103765 expression and it promotes apoptosis, while silencing circRNA-103765 protects against TNF- $\alpha$-induced apoptosis of human intestinal epithelial cells (ECs). Thus, blocking circRNA-103765 may be a novel approach for the treatment of IBD patients (15). A study found that the expression of circRNA-102685 was upregulated in the colonic tissue of $\mathrm{CD}$ patients compared to healthy controls. Therefore, in CD pathogenesis, circRNA-102685 may regulate the expression of target genes through miR-146 (16). HuR (encoded by the Elavl1 gene) has become the main posttranscriptional regulator of intestinal epithelial homeostasis and it is a widely studied RNA binding protein (RBP) (17). To regulate ATG16L1 translation, $\mathrm{HuR}$ regulates autophagy by interacting with circPABPN1 in intestinal epithelial cells. Autophagy is generally considered to benefit cell, tissue, and organ homeostasis and it is involved in intestinal mucosal defense and barrier function (18). It has been shown that transcription of CDKN2B-AS11 into circular RNA with specific functions increases cell proliferation, increases cell adhesion, and decreases apoptosis $(19,20)$. Some studies have found that in UC patients, CDKN2B-AS1 is significantly downregulated, whereas linear and circular CDKN2B-AS1 affects the proliferation of colonic epithelial cells. A decrease in the expression of CDKN2B-AS1 enhances the formation of the colonic epithelium monolayer barrier by destroying 


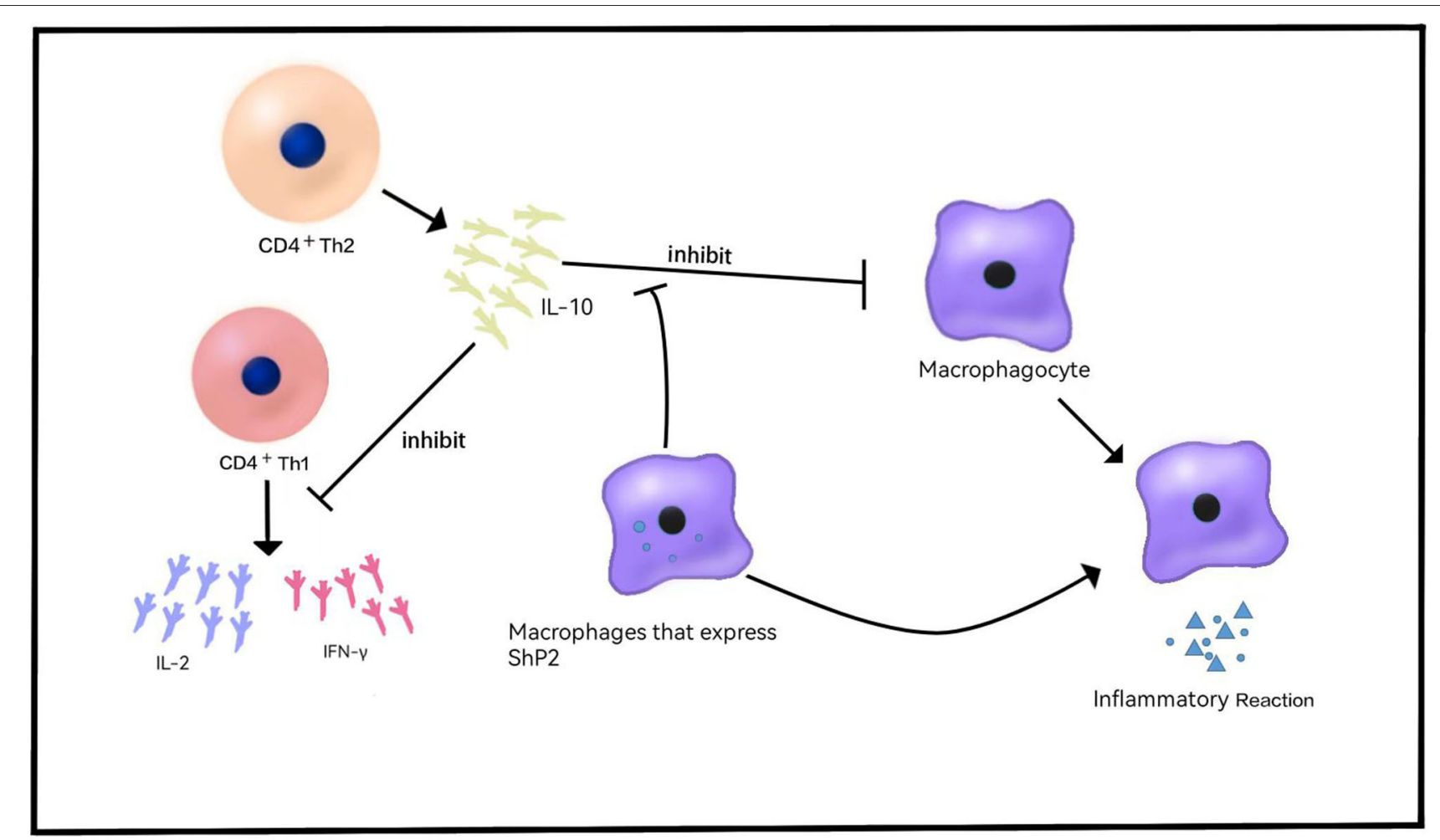

FIGURE 1 | Role of IL-10 in VEO-IBD. IL-10 is released by CD4+ Th2 cells and inhibits the release of cytokines such as IL-2 and IFN- $\gamma$. IL-10 inhibits the release of inflammatory cytokines and the inflammatory response. Shp2 can reduce the sensitivity of macrophages to IL-10 and produce proinflammatory effects.

Claudin-2 expression (21). Inspired by these studies, a new direction for the targeting of therapeutic drugs is provided by these circRNAs.

\section{IMMUNE DYSREGULATION}

The gastrointestinal tract is the largest immune organ in the human body, so it is not surprising that people with immunodeficiency have an increased risk of developing IBD. The progress of high-throughput sequencing technology helps describe single gene abnormalities, which change the intestinal dynamic balance through multiple mechanisms, including dysfunction of the epithelial barrier, abnormalities of $\mathrm{T}$ and $\mathrm{B}$ lymphocytes, a decrease in neutrophils, a defect in the phagocyte ability to kill bacteria and a lack of intestinal innervation.

\section{Cytokines and Their Receptors}

IL-10 was originally described as a soluble factor released by $\mathrm{CD} 4+\mathrm{Th} 2$ cells that can preclude the release of CD4+ Th1 cytokines, such as IL-2 and IFN- $\gamma$ (22) (Figure 1). Subsequently, it was found that IL-10 is secreted by a variety of cells and has multiple effects on $\mathrm{T}$ and Blymphocytes, bone marrow cells, etc. In 2009, mutation of IL-10RA-IL-10RB was found in infants with IBD, providing a new comprehension of the pathogenesis of IBD (23), which is consistent with the conclusion of previous studies that the lack of an anti-inflammatory effect of IL-10 causes the activation of an explosive intestinal immune response. These mutations are associated with severe intestinal inflammation, especially in neonatal or infantile VEO-IBD with a phenotype of severe enterocolitis and perianal disease (24). IBD-like immunopathology appears in all patients with IL-10 signaling blocking mutations, showing that these defects are a single gene form of IBD with a penetrance of $100 \%(24,25)$. According to recent immunological studies, IL-10R1 is expressed in many cells involved in innate immunity or acquired immunity, while IL-10RB is an integral part of the receptors of IL-22, IL26 , IL-28 and IL-28 $\beta$, and it is expressed in immunocytes or non-immunocytes (26). IL-10 polymorphism is associated with the risk of colitis (27), implying that genetic variation in the IL-10-dependent pathway may be related to the pathogenesis of inflammatory bowel disease.

TGF $\beta$ constitutes a key factor in the differentiation of regulatory $\mathrm{T}$ cells (Tregs) and Th17 cells. TGF $\beta$ is nonredundantly required for the generation of Tregs (28) but essential for the development of Th17 cells (29). IL-1 $\beta$ can take the place of TGF $\beta$ in IL-6-mediated generation of Th17 cells (30). In the absence of pro-inflammatory signals, such as IL-6 produced by microbial-activated dendritic cells (DCs) or IL-21 secreted by IL-6-stimulated $\mathrm{T}$ cells, priming of naïve CD4+ T cells in an environment rich in TGF $\beta$ promotes the development of iTregs (31) in response to antigens. In contrast, activation in an environment wherein both TGF $\beta$ and IL- 6 are available promotes Th17 development, at least at mucosal sites (32). At low concentrations, TGF $\beta$ synergizes with IL- 6 and IL-21 to increase 


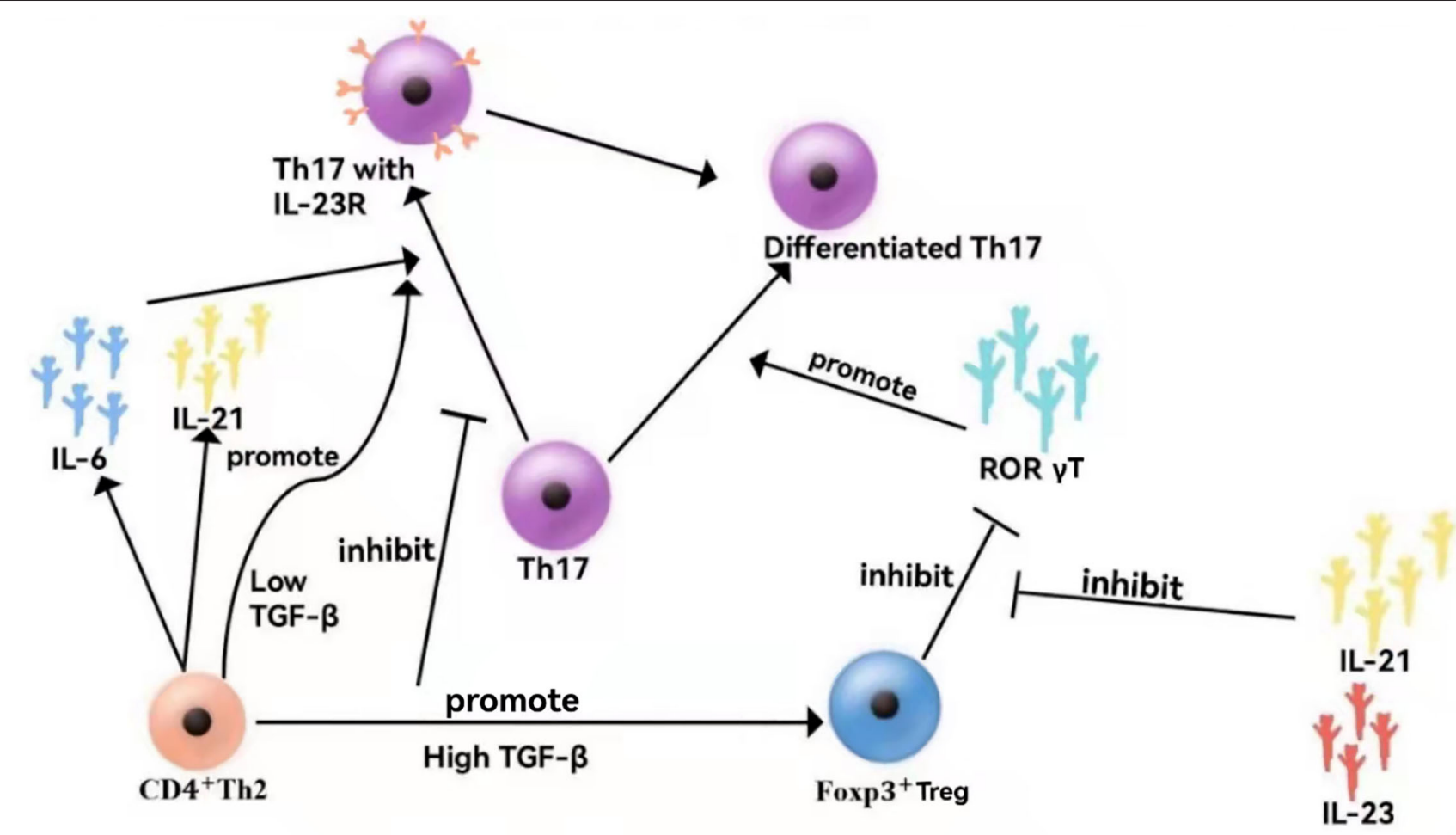

FIGURE 2 | Cytokine networks in VEO-IBD. At low concentrations, TGF synergistically with IL-6 and IL-21 promotes the expression of the IL-23 receptor (IL-23R), facilitating Th17 differentiation. At high concentrations, TGF inhibits IL-23R, which is beneficial to Foxp3+ Tregs, thereby inhibiting the function of ROR $\gamma \top$ cells. In contrast, IL-21 and IL-23 reduce Foxp3 ${ }^{+}$-mediated inhibition of ROR $\gamma \mathrm{T}$, thereby promoting Th17 differentiation.

IL-23 receptor (IL-23R) expression, favoring Th17 differentiation $(33,34)$, whereas at high concentrations, TGF $\beta$ represses IL23R and favors Foxp3+ Tregs, which in turn restrains ROR $\gamma \mathrm{t}$ function (35). In contrast, the amelioration of IL-21 and IL23 toward Foxp3-mediated inhibition of ROR $\gamma$ t facilitates Th17 differentiation (Figure 2).

In a controlled clinical trial, altered methylation of interleukin (IL-6) and transforming growth factor $\beta 1$ (TGF- $\beta 1$ ) was detected. The logistic regression analysis showed that a combination of 14 CPGs in TGF- $\beta 1$ and 4 CPGs in IL- 6 provides a new way to identify children with $\mathrm{CD}$ and that CPGs, and the proximal fragment of the promoter of the TGF- $\beta 1$ gene, discriminated quite accurately between children with UC and controls. The results of this controlled trial suggest that a combination of DNA methylation of TGF- $\beta 1$ and IL- 6 could provide very high accuracy in distinguishing between $\mathrm{CD}$ and control patients and that further expansion of the sample content could detect even more accurate variations. This provides a new way of diagnosing and classifying children with VEO-IBD (36).

\section{T and B Lymphocytes and Complex Function Defects}

Loss of LRBA function mutations causes multiple defects in the immune cell population, which ultimately leads to the VEOIBD phenotype (37). Arp2/3 and CARMIL2, also known as RLTPR, regulate the cytoskeleton, endocytosis, and cell migration by controlling actin polymerization (38). This study noted that CARMIL2 deficiency can produce an IBD-like phenotype, which may be related to the significant decrease in Foxp3+ Tregs in patients with CARMIL2 deficiency. Moreover, providing another important molecular example for PID to show the characteristics of VEO-IBD, this study placed great emphasis on the important role of CARMIL2-mediated immunity in regulation of the balance of the intestinal environment. The results of this study also suggested that the lack of a serious autoimmune phenotype in CARMIL2 deficiency may be caused by the deficiency of memory $\mathrm{T}$ cell differentiation and CD28-mediated dysfunction of effector T cell activation, but further research on CARMIL 2 is required to confirm this hypothesis.

Based on the relevant research results, we have summarized the existing and relatively comprehensive research conclusions, providing intuitive and useful conclusions (Table $\mathbf{1}$ ).

\section{Epithelial Barrier Function Defects}

Villous blunting or atrophy barely occurs in adult IBD coteries but it occurs in as many as $20 \%$ of VEO-IBD coteries (51). Junctional adhesion molecule-A (JAM-A) constitutes a key structure of tight junctions and it is essential for the control of cell migration into the underlying tissues. Moreover, studies of CD tissue specimens revealed a loss of epithelial JAM-A expression (64). In line with these findings, decreased levels of other tight junction proteins, such as claudins, were observed in CD (62). 
TABLE 1 | List of gene mutations associated with monogenic VEO-IBD and IBD-like colitis.

\begin{tabular}{|c|c|c|}
\hline Genes & $\begin{array}{l}\text { Clinical } \\
\text { syndromes }\end{array}$ & Studies \\
\hline \multicolumn{3}{|l|}{ Immune dysregulation } \\
\hline NOD2 & Susceptibility gene & Travassos et al. (6) \\
\hline ATG16L1 & Susceptibility gene & Homer et al. (39) \\
\hline TRIM22 & $\begin{array}{l}\text { NOD2 signaling } \\
\text { defects }\end{array}$ & Li et al. (40) \\
\hline IL-10 & $\begin{array}{l}\text { Neonatal or } \\
\text { infantile VEO-IBD }\end{array}$ & Kotlarz et al. (24) \\
\hline IL-10RA & $\begin{array}{l}\text { Neonatal or } \\
\text { infantile VEO-IBD }\end{array}$ & Glocker et al. (23) \\
\hline IL-10RB & $\begin{array}{l}\text { Neonatal or } \\
\text { infantile VEO-IBD }\end{array}$ & Glocker et al. (23) \\
\hline FOXP3 & IPEX & $\begin{array}{l}\text { Torgerson and Ochs } \\
(41)\end{array}$ \\
\hline \multicolumn{3}{|c|}{ Hyperinflammatory and autoimmune disorders } \\
\hline XIAP & $\begin{array}{l}\text { X-linked } \\
\text { lymphoproliferative } \\
\text { syndrome } 2\end{array}$ & Latour and Aguilar (42) \\
\hline SLC11A1 & Susceptibility gene & Sechi et al. (43) \\
\hline CTLA4 & $\begin{array}{l}\text { Autoimmune } \\
\text { lymphoproliferative } \\
\text { syndrome }\end{array}$ & Kuehn et al. (44) \\
\hline PLCG2 & $\begin{array}{l}\text { Autoinflammation } \\
\text { and PLC } 2 \text { - } \\
\text { associated } \\
\text { antibody } \\
\text { deficiency, and } \\
\text { immune } \\
\text { dysregulation } \\
\text { (APLAID) }\end{array}$ & Zhou et al. (45) \\
\hline STAT3 & $\begin{array}{l}\text { Multisystem } \\
\text { autoimmune } \\
\text { disease }\end{array}$ & Duerr et al. (46) \\
\hline IL23R & Susceptibility gene & Duerr et al. (46) \\
\hline CCR6 & Susceptibility gene & Duerr et al. (46) \\
\hline TNFSF15 & Susceptibility gene & Duerr et al. (46) \\
\hline Shp2 & Susceptibility gene & Xiao et al. (47) \\
\hline miR-320a & CD and UC & Fasseu et al. (11) \\
\hline let-7c & $\mathrm{CD}$ and $\cup C$ & Banerjee et al. (48) \\
\hline \multicolumn{3}{|c|}{$T$ cell, B cell, and complex function defects } \\
\hline LRBA & CVID 8 & Alangari et al. (37) \\
\hline ZAP70 & ZAP70 deficiency & Chan et al. (49) \\
\hline WAS & $\begin{array}{l}\text { Wiscott-Aldrich } \\
\text { syndrome }\end{array}$ & Catucci et al. (50) \\
\hline CARMIL2 & VEO-IBD, SCID & Magg et al. (38) \\
\hline RAG2 & Omenn syndrome & Kelsen et al. (51) \\
\hline RAG1 & Omenn syndrome & Villa et al. (52) \\
\hline DCLRE1C/ARTEMIS95 & Omenn syndrome & Villa et al. (52) \\
\hline MALT1 & SCID & Punwani et al. (53) \\
\hline DOCK8 & $\begin{array}{l}\text { Hyper } \\
\text { immunoglobulin E } \\
\text { syndrome }\end{array}$ & Sanal et al. (54) \\
\hline CD4OLG & $\begin{array}{l}\text { Hyper } \\
\text { immunoglobulin M } \\
\text { syndrome }\end{array}$ & Levy et al. (55) \\
\hline
\end{tabular}

(Continued)
TABLE 1 | Continued

\begin{tabular}{|c|c|c|}
\hline Genes & $\begin{array}{l}\text { Clinical } \\
\text { syndromes }\end{array}$ & Studies \\
\hline AICDA & $\begin{array}{l}\text { Hyper } \\
\text { immunoglobulin M } \\
\text { syndrome }\end{array}$ & Quartier et al. (56) \\
\hline \multicolumn{3}{|c|}{ Epithelial barrier function defects } \\
\hline COL7A1 & $\begin{array}{l}\text { Dystrophic } \\
\text { epidermolysis } \\
\text { bullosa }\end{array}$ & Zimmer et al. (57) \\
\hline ADAM17 & $\begin{array}{l}\text { ADAM17 } \\
\text { deficiency }\end{array}$ & Chalaris et al. (58) \\
\hline IKBKG & $\begin{array}{l}\text { X-linked } \\
\text { ectodermal } \\
\text { immunodeficiency } \\
\text { (NEMO) }\end{array}$ & $\begin{array}{l}\text { Karamchandani-Patel } \\
\text { et al. (59) }\end{array}$ \\
\hline FERMT1 & Kindler syndrome & Sadler et al. (60) \\
\hline TTC7A & TTC7A deficiency & Avitzur et al. (61) \\
\hline GUCY2 & Familial diarrhea & Uhlig (4) \\
\hline $\begin{array}{l}\text { CDKN2B- } \\
\text { AS11 }\end{array}$ & UC & Rankin et al. (21) \\
\hline CircRNA_103765 & IBD & Ye et al. (15) \\
\hline Claudin2 & IBD & Zeissig et al. (62) \\
\hline HuR & Colitis & Pott et al. (18) \\
\hline $\operatorname{miR}-126$ & IBD & Chen et al. (12) \\
\hline \multicolumn{3}{|l|}{ Others } \\
\hline FUT2 & Susceptibility gene & McGovern et al. (63) \\
\hline
\end{tabular}

Defects in intestinal epithelial barrier function can be involved in VEO-IBD processes, including loss-of-function mutations in ADAM17 resulting in ADAM17 deficiency (65), IKBKG (encoding NEMO) mutation producing X-linked ectodermal dysplasia and immunodeficiency (59), and COL7A1 mutation causing dystrophic epidermolysis bullos (57). FERMT1 mutation results in Kindler syndrome (66), and TTC7A (61) or gain-offunction mutations in GUCY2 cause familial diarrhea $(4,67)$.

\section{INTESTINAL ENVIRONMENTAL FACTORS}

It has been proven that the interaction between the gut microbiota, metabolites, and the gut immune system is essential for maintaining a healthy gut (68). Specific alterations in the composition and function of the gut microbiota may be used as microbial biomarkers for the diagnosis of IBD, disease activity, response to therapy, and prediction of outcomes.

For newly diagnosed children with IBD, an increase in the number of Proteobacteria in the intestinal microbiota and a decrease in the number of Faecalibacterium prausnitzii appear to be associated with a complex disease phenotype and a subsequent need for biological therapy or surgery (69). The most common finding was an increase in adherent-aggressive Escherichia coli in the gut of IBD patients. This infectious agent can adhere to and cross the intestinal mucus barrier and invade the upper intestinal cortex. Second, compared with 
non-gastroenteritis patients, Salmonella fecal culture-positive gastroenteritis patients were significantly associated with an increased risk of new $\mathrm{UC}$ and $\mathrm{CD}$. The most recent national case-control study from Sweden also demonstrated a positive association between a Salmonella diagnosis and the likelihood of IBD, and this study found that Clostridium difficile was associated with higher rates of UC and CD (70). Additionally, the latest and most comprehensive meta-analysis found a $57 \%$ lower risk of Helicobacter pylori exposure and inflammatory bowel disease, including CD and UC (71), and a meta-analysis that included only Asian studies reported consistent results (72). This protective association may be mediated, at least in part, by the specific components of $H$. pylori strains through immune regulation.

In addition to bacteria, some studies have found that VEO-IBD is also linked to enteroviruses. In a study of enterovirus, norovirus G-I, norovirus G-II, rotavirus, astrovirus, and sand wave virus RNA in fecal samples from 33 children with IBD and 17 children without IBD, viral RNA was detected only in children without IBD (3\% vs. $0 \%)$ (73). Given changes in the intestinal microbiota in IBD patients, current clinical guidelines recommend testing for $C$. difficile in all IBD patients with exacerbating or newly emerging diarrhea and testing for cytomegalovirus in severely active IBD patients, especially when steroids and medications are used together to treat refractory disease.

Patients with CD exhibit significant differences in their gut metabolome, including lower concentrations of short-chain fatty acids $(74,75)$, higher concentrations of amino acids (75), and a dysregulated bile acid composition, including higher concentrations of conjugated bile acids and lower concentrations of secondary bile acids (76). In a cohort study, a strong association was found between an increase in the number of antibiotic prescriptions in the first year of life and the onset of IBD in childhood. In this study, the use of antibiotics, particularly in infancy, could lead to changes in the gut microbiota, suggesting they have a vital role in development of the immune system (77).

\section{THERAPEUTIC METHODS}

\section{Medications}

The standard therapeutic choices for VEO-IBD include 5-ASA, steroids, immunomodulators (6MP, azathioprine, methotrexate), and anti-TNF antibodies. At present, there are few studies that have been carried out in the pediatric patient population, and the relevant clinical data are insufficient, most of which are similar to polygenic IBD. It is more important to understand the data on drug-related dosage and adverse reactions (Table 2). Among the available medications, infliximab, vedolizumab, and ustekinumab are used in the treatment of VEO-IBD.

Monoclonal antibodies against tumor necrosis factor $\alpha$ (TNF$\alpha$ ), such as infliximab (IFX) or adalimumab (ADA), are safe and effective in inducing and maintaining remission in moderateto-severe pediatric Crohn's disease (CD), and ulcerative colitis
(UC) patients $(78,79)$. Based on the experience of a tertiary center in Japan, IFX treatment seems to be more effective for non-ulcerative colitis type (NUCT) and non-ulcerative colitis type without perianal disease (NUC-NPD) patients, and it seems that their height and weight are improved after treatment (80). However, the use of TNF inhibitors is limited, even among TNF responders, because of systemic side effects, including immunosuppression and cardiotoxicity. In addition, up to onethird of patients do not respond to TNF- $\alpha$ antagonist therapy, and $\sim 20 \%$ of primary responders may experience response loss each year $(81,82)$. Therefore, in recent years, the FDA has approved some bio-similars ofTNF- $\alpha$ antagonists for the treatment ofVEO-IBD. The biosimilar agent infliximab is an immunoglobulin G(IgG) anti-TNF- $\alpha$ monoclonal antibody that binds to soluble and transmembrane forms of TNF- $\alpha$, which can further impede its interaction with the TNF receptors TNFR1 (P55) and TNFR2 (P75) on the surface of target cells. Therefore, it can be used to treat pediatric IBD $(83,84)$. Nonetheless, the biosimilar adalimumab has not yet been approved for pediatric IBD (85).

Vedolizumab (VDZ) is a humanized monoclonal antibody that specifically identifies lymphocyte integrin $4 \beta 7$ receptors and prevents them from migrating from the blood vessels into the intestinal mucosa, thereby reducing the flow of white blood cells into inflammatory tissues. As an intestinal selective anti-integrin drug, it has been reported to have a low risk of infection $(86,87)$. In the first study of VDZ in children with VEO-IBD, this antiintegrin agent was shown to be safe and effective in the study population. Similarly, in the Porto group study, 16 pediatric patients found VDZ was safe and well-tolerated-1 developed upper respiratory tract infection $(6.3 \%)$, and two developed joint pain $(12.5 \%)$ (88). Conrad et al. also evaluated VDZ for severe IBD in children with similar results (89). Another multicenter study published in 2016 demonstrated the efficacy and safety of VDZ in the pediatric population (90). VDZ is not approved for pediatric patients but has demonstrated clinical efficacy for pediatric IBD. Its remission rates of $\mathrm{UC}$ and $\mathrm{CD}$ are 76 and $42 \%$, respectively $(89,90)$.

Ustekinumab, a therapeutic human IgG1 monoclonal antibody (mAb) targeting the interleukin (IL)-12/IL-23 shared p40 subunit, is approved in adolescents (12 years of age and older) for the treatment of moderate and severe psoriasis, as well as for the treatment of adult celiac disease and UC (91)while celiac disease currently has gluten-free diet as the only therapy. In a multicenter prospective cohort of children, the effectiveness of ustekinumab in treating refractory UC was demonstrated (92), which is similar to the results of a retrospective study of pediatric IBD, suggesting that ustekinumab is effective and safe in children with IBD (93). Some case reports suggest that $50 \%$ of children with IBD have a clinical response to ustekinumab $(94,95)$. In a cohort of pediatric patients with $\mathrm{CD}$, patients using ustekinumab had significant improvements in their abbreviated pediatric CD activity index (aPCDAI) scores, clinical remission rates, albumin, and hematocrit, and $89.5 \%$ of patients had no significant adverse events (96). The use of off-label drugs is increasing in children with IBD and generally they are being reported as safe and effective (93). 
TABLE 2 | Dose, interval, adverse reactions to medications for pediatric and VEO-IBD.

\begin{tabular}{|c|c|c|c|c|}
\hline Therapy & & $\begin{array}{l}\text { Therapeutic } \\
\text { doses }\end{array}$ & The time interval & Adverse effects \\
\hline $\begin{array}{l}\text { Exclusive enteral } \\
\text { nutrition therapy }\end{array}$ & & $\begin{array}{l}\text { Starting from } \\
10-20 \mathrm{ml} /\left(\mathrm{kg}^{\star} \mathrm{d}\right) \\
\text { the speed of } \\
\text { increasing } 10-20 \\
\mathrm{ml} /\left(\mathrm{kg}^{\star} \mathrm{d}\right)\end{array}$ & $\begin{array}{l}\text { Total treatment: } 6 \\
\text { weeks, then } \\
\text { 2-week course of } \\
\text { EEN tapering and } \\
\text { gradual } \\
\text { introduction of a } \\
\text { habitual diet }\end{array}$ & $\begin{array}{l}\text { Anatomical } \\
\text { extension, } \\
\text { perianal disease, } \\
\text { stricturing behavior, diarrhea, } \\
\text { vomiting, constipation, } \\
\text { dehydration, feeding tube } \\
\text { blockage, dyspnea and hypoxia, } \\
\text { aspiration pneumonia. }\end{array}$ \\
\hline Ustekinumab & & $90 \mathrm{mg}$ & $\begin{array}{l}\text { Every } 8 \\
\text { weeks/every } \\
4 \text { weeks }\end{array}$ & $\begin{array}{l}\text { Arthralgia, skin } \\
\text { eruption, cough, } \\
\text { spondylarthritis, cardiovascular } \\
\text { disease, infection, malignant } \\
\text { tumor, headache. }\end{array}$ \\
\hline Vedolizumab & & $300 \mathrm{mg}$ & $\begin{array}{l}0,2 \text { and } 6 \text { weeks, } \\
\text { then every } 8 \\
\text { weeks }\end{array}$ & $\begin{array}{l}\text { Nausea, headache, } \\
\text { malaise, } \\
\text { spondylarthritis, bronchitis, liver } \\
\text { function injury, fever, fatigue, } \\
\text { back pain, limb pain, rash, } \\
\text { pruritus, progressive multifocal } \\
\text { leukoencephalopathy, infusion } \\
\text { related reactions and } \\
\text { hypersensitivity reactions. }\end{array}$ \\
\hline \multirow[t]{3}{*}{ Anti-TNF } & Infliximab & $5 \mathrm{mg} / \mathrm{kg}$ & $\begin{array}{l}0,2 \text { and } 6 \text { weeks, } \\
\text { then every } 8 \\
\text { weeks }\end{array}$ & $\begin{array}{l}\text { (1) Acute infusion reactions: } \\
\text { urticaria, fever, dyspnea, etc. } \\
\text { (2) Delayed response: arthralgia, } \\
\text { fever, rash, edema, and } \\
\text { headache. }\end{array}$ \\
\hline & Adalimumab & $\begin{array}{l}\text { Induction period of } \\
4 \text { weeks, } \\
\text { subcutaneous } \\
\text { immunization } \\
\text { Standard dose: } 20 \\
\text { mg/kg or } 40 \\
\text { mg/kg every week. } \\
\text { Low dose: } 10 \\
\text { mg/kg or } 20 \\
\text { mg/kg every week. }\end{array}$ & $\begin{array}{l}<40 \mathrm{~kg}: 0 \text { week, } \\
80 \mathrm{mg} .2 \text { week, } \\
40 \mathrm{mg} . \\
>40 \mathrm{~kg}: 0 \text { week, } \\
160 \mathrm{mg} .2 \text { week, } \\
80 \mathrm{mg} .\end{array}$ & $\begin{array}{l}\text { (3) Infectious complications: } \\
\text { urinary tract infection, } \\
\text { pneumonia, cellulitis, mastitis, } \\
\text { influenza and tuberculosis. } \\
\text { (4) Cardiovascular system } \\
\text { response. } \\
\text { (5) Reactions: multiple sclerosis, } \\
\text { paresthesia, and seizures. } \\
\text { Malignant neoplasms and } \\
\text { lupus-like syndrome. }\end{array}$ \\
\hline & Golimumab & $2 \mathrm{mg} / \mathrm{kg}$ & $\begin{array}{l}0,4 \text { weeks, } \\
\text { then every } \\
8 \text { weeks }\end{array}$ & \\
\hline \multirow[t]{2}{*}{ CTLA4 agonists } & Abatacept & $\begin{array}{l}<75 \mathrm{~kg}, 10 \mathrm{mg} / \mathrm{kg} \\
\geq 75 \mathrm{~kg}, 750 \mathrm{mg} \\
\text { the maximum } \\
\text { dose cannot } \\
\text { exceed } 1000 \mathrm{mg}\end{array}$ & $\begin{array}{l}0,2 \text {, and } 4 \text { weeks, } \\
\text { then every } 4 \\
\text { weeks }\end{array}$ & $\begin{array}{l}\text { (1) Discoid lupus, cutaneous } \\
\text { vasculitis, erythema nodosum, } \\
\text { skin infections, skin tumors. } \\
\text { (2) Conditional infections: } \\
\text { pathogenic pneumonia, sepsis. } \\
\text { (3) Hematological toxicity. } \\
\text { (4) Pulmonary sarcoidosis. } \\
\text { (5) Tuberculous uveitis, eye } \\
\text { pigment layer inflammation. }\end{array}$ \\
\hline & Ipilimumab & 3 mg/kg & Every 3 weeks & $\begin{array}{l}\text { (1) Common adverse effects: } \\
\text { insomnia, joint pain. } \\
\text { (2) Serious adverse effects: } \\
\text { oliguria, hematuresis, diarrhea, } \\
\text { stomachache, cough, chest pain } \\
\text { or wheezing, fatigue, memory } \\
\text { problems, hallucinations, } \\
\text { seizures, or neck stiffness, } \\
\text { diureses weight loss, sweat, } \\
\text { constipation, depression. }\end{array}$ \\
\hline
\end{tabular}


From limited evidence, dual biotherapy may be a safe option for patients with refractory IBD who have failed multiple biotherapies and for managing the extra-intestinal presentation of IBD (97). A cohort of refractory pediatric IBD reported the effectiveness and safety of dual biologics or a combination of biologics and JAK inhibitors (98). In a case series and review of the literature, eight children received a combination of infliximab and vedolizumab, and five children received a combination of infliximab and ustekinumab, which shows combining biological agents to be safe and beneficial in selected patients (99). However, larger studies are required to confirm the preliminary safety data that were observed.

Ruxolitinib, a selective JAK1/2 inhibitor, was found in a single-center retrospective study of patients with refractory VEOIBD with AIP to be primarily used for dual therapy when complete remission was not achieved with primary therapy. All patients in this study showed clinical improvement and did not require complete parenteral nutrition or steroids. Other potential benefits of ruxolitinib included a lack of immunogenicity, a rapid onset of action, and a short half-life. In addition, ruxolitinib can be administered entirely with sufficient enteral absorption to achieve a clinical response in a cohort with severe intestinal disease. However, this study still has limitations and could not determine whether ruxolitinib will be effective or safe in general use (100).

\section{Exclusive Enteral Nutrition Therapy}

Exclusive enteral nutrition therapy (EEN) is the preferred treatment for European VEO-IBD patients. In a propensity score matching cohort analysis of children with Crohn's disease induced by total enteral nutritionor glucocorticoids (CSs) (101), EEN, and CSs were found to be equally effective in inducing remission. Through a central retrospective analysis, EEN was found to be more effective than CSs in improving nutritional status and growth recovery, with relatively few side effects. More importantly, EEN can achieve mucosal healing $(\mathrm{MH})$, which is the target of CD treatment. When applied in an early stage, $\mathrm{MH}$ reduces the incidence of hospitalization, surgical resection, and fistula formation, providing a new pattern for the treatment of very early inflammatory bowel disease. Some data show that the intestinal flora, amino acids, and fecal metabolites of CD patients have significant changes before and after EEN treatment (102), providing a biochemical detection method for judging the efficacy of EEN.

\section{Hematopoietic Stem Cell Transplantation}

Due to events such as severe or opportunistic infections and malignancies associated with biologic methods, stem cell transplantation has entered clinical trials as a more permanent treatment for IBD. Allogeneic hematopoietic stem cell transplantation (allo-HSCT) is an established therapeutic option for VEO-IBD. In a retrospective investigation of autologous hematopoietic stem cell transplantation for CD, MSC therapy may be an alternative to endovenous and fistula treatment (103). In terms of IPEX and IL-10 signaling deficits, HSCT has been shown to improve colitis and gastrointestinal fistula $(104,105)$. VEO-IBD patients with IL-10R deficiency can also be cured by
allo-HSCT $(23,106)$. However, 11 patients with transplanted IL-10 and IL-10R deficiency showed a very high frequency of primary graft rejection (3/11), and these data suggest that patients with either IL-10 or IL-10R deficiency need to have their transplant regimen adjusted to reduce the risk of rejection (105, 106). Therefore, the use of post-transplant cyclophosphamide and bone marrow transplantation with T cell-identical cells have been considered potential therapies for patients with IL-10R deficiency (107). Similarly, studies have shown that allogeneic hematopoietic stem cell transplantation can successfully treat XIAP-deficient idiopathic colitis with specific conditioning regimens (108). For patients with a refractory IBD phenotype and an increased risk of mortality due to XIAP deficiency, HSCT should be considered as early as possible, as it can address their risk of intestinal inflammation and the development of lifethreatening hemophilic lymphocytosis (109). However, HSCT is not effective for all cases of VEO-IBD. IBD lacking NEMO or TTC7A cannot be improved after HSCT and it may even worsen $(110,111)$. Therefore, we believe that the application of therapeutic HSCT in certain conditions is promising, but it should always be personalized.

Bone marrow MSCs can promote wound healing and tissue regeneration by secreting TGF- $\beta$ and fibroblast growth factor. This property offers a new approach to the treatment of CD with fistulae.

\section{Surgery}

Despite recent advances in treatments, surgery still plays an important role in the management of VEO-IBD. Although surgery cannot cure VEO-IBD, in some cases, it can help resolve acute complications and maintain remission, allowing diseasefree intervals, and nutritional recovery (112), and has a huge impact on physical and mental development (113). The main indications for surgery in $\mathrm{CD}$ are unresponsive and refractory to maximum medical treatment, fistula, perforation, stricturing disease, and severe perianal disease. Meanwhile, acute indications for UC surgery also include toxic megacolon, which is rare in children. A systematic review noted that surgical rates for $\mathrm{CD}$ ranged from 10 to $72 \%$, while colectomy rates for UC ranged from 0 to $50 \%$ (113). Minimally invasive surgery has also been used for the radical treatment of CD and UC since 2002. In recent years, robotic surgery, a single-hole approach and minimally invasive treatment of perianal fistula CD have been adopted (114).

\section{Other Treatments}

Two recent randomized controlled trials (RCTs) provided additional insight by suggesting that rebuilding the intestinal microbiota composition through fecal microflora transplantation (FMT) can improve UC activity in this patient subgroup (115, 116). Although a few nonrandomized control studies have been performed in older children (youngest child 7 years old) (117), the efficacy of FMT for VEO-IBD is unclear.

The use of immunosuppressive drugs in the treatment regimen increases the risk of infectious diseases and infectionrelated complications in children with IBD. Therefore, 
vaccination to prevent related infections is an important aspect of long-term care of this disease.

\section{CONCLUSION}

Current studies show that the pathogenesis of VEO-IBD includes genetic factors, immune molecular factors, and changes in the intestinal environment. With research progress on the susceptibility genes of IBD, the localization of the susceptibility genes of IBD helps identify and distinguish the disease phenotype, track the clinical progress, and ultimately develop new targeted therapies. However, due to the lack of clinical follow-up data in VEO-IBD children, there are still great challenges in terms of the drug efficacy and the research and development (R\&D) of new drugs. It is not enough to draw lessons from the adult treatment experience alone. In the future, rapid diagnosis and management of children should be carried out, diagnosis, and treatment criteria based on genetic abnormalities should be established, and a clinical database should be expanded. We need to establish control groups and explore the influence of environmental factors on the incidence, treatment and prognosis of VEO-IBD. Finally, a precision medicine model needs to be achieved, namely, individualized treatment for VEO-IBD children.

\section{REFERENCES}

1. Miller TL, Lee D, Giefer M, Wahbeh G, Suskind DL. Nutritional therapy in very early-onset inflammatory bowel disease: a case report. Digest Dis Sci. (2017) 62:2196-200. doi: 10.1007/s10620-017-4616-9

2. Kelsen JR, Sullivan KE, Rabizadeh S, Singh N, Snapper S, Elkadri A, et al. North american society for pediatric gastroenterology, hepatology, and nutrition position paper on the evaluation and management for patients with very early-onset inflammatory bowel disease. J Pediatr Gastroenterol Nutr. (2020) 70:389-403. doi: 10.1097/MPG.0000000000002567

3. Zhang YZ, Li YY. Inflammatory bowel disease: pathogenesis. World J Gastroenterol. (2014) 20:91-9. doi: 10.3748/wjg.v20.i1.91

4. Uhlig HH. Monogenic diseases associated with intestinal inflammation: implications for the understanding of inflammatory bowel disease. Gut. (2013) 62:1795-805. doi: 10.1136/gutjnl-2012-303956

5. Parkhouse R, Monie TP. Dysfunctional Crohn's disease-associated NOD2 polymorphisms cannot be reliably predicted on the basis of RIPK2 binding or membrane association. Front Immunol. (2015) 6:521. doi: 10.3389/fimmu.2015.00521

6. Travassos LH, Carneiro LA, Ramjeet M, Hussey S, Kim YG, Magalhaes JG, et al. Nod1 and Nod2 direct autophagy by recruiting ATG16L1 to the plasma membrane at the site of bacterial entry. Nat Immunol. (2010) 11:55-62. doi: $10.1038 /$ ni.1823

7. Cooney R, Baker J, Brain O, Danis B, Pichulik T, Allan P, et al. NOD2 stimulation induces autophagy in dendritic cells influencing bacterial handling and antigen presentation. Nat Med. (2010) 16:90-7. doi: 10.1038/nm.2069

8. Jensen MD, Andersen RF, Christensen $H$, Nathan $T$, Kjeldsen J, Madsen JS. Circulating microRNAs as biomarkers of adult Crohn's disease. Eur J Gastroenterol Hepatol. (2015) 27:1038-44. doi: 10.1097/MEG.0000000000000430

9. Batra SK, Heier CR, Diaz-Calderon L, Tully CB, Fiorillo AA, van den Anker J, et al. Serum miRNAs are pharmacodynamic biomarkers associated with therapeutic response in pediatric inflammatory bowel disease. Inflamm Bowel Dis. (2020) 26:1597-606. doi: 10.1093/ibd/izaa209

\section{AUTHOR CONTRIBUTIONS}

Q-QL and H-HZ drafted the article and approved the final manuscript as submitted.

\section{FUNDING}

This study was supported by the High-Level Personnel Program of Guangdong Provincial People's Hospital (2021DFJH0008/KY012021458), Starting Program for National Natural Science Foundation of China at Guangdong Provincial People's Hospital (8207034250), National Natural Science Foundation of China (NSFC, No. 81300370), China Postdoctoral Science Foundation (CPSF, No. 2018T110855 of Special Support Program and No. 2017M622650 of General Support Program), Natural Science Foundation of Guangdong (NSFG, No. 2018A030313161), Southern Medical University (12440000771868596D), S-XD is a supervisor at the Second Clinical School of Southern Medical University and an adjunct associate professor at Southern Medical University, and supervised Q-QL and $\mathrm{H}-\mathrm{HZ}$ in New Insights and Advances in Pathogenesis and Treatment of Very Early Onset Inflammatory Bowel Disease.

10. Paterson MR, Kriegel AJ. MiR-146a/b: a family with shared seeds and different roots. Physiol Genomics. (2017) 49:243-52. doi: 10.1152/physiolgenomics.00133.2016

11. Fasseu M, Treton X, Guichard C, Pedruzzi E, Cazals-Hatem D, Richard C, et al. Identification of restricted subsets of mature microRNA abnormally expressed in inactive colonic mucosa of patients with inflammatory bowel disease. PLoS ONE. (2010) 5: e13160. doi: 10.1371/journal.pone.0013160

12. Chen $\mathrm{T}$, Xue $\mathrm{H}$, Lin $\mathrm{R}$, Huang $\mathrm{Z}$. MiR-126 impairs the intestinal barrier function via inhibiting S1PR2 mediated activation of PI3K/AKT signaling pathway. Biochem Biophys Res Commun. (2017) 494:427-32. doi: 10.1016/j.bbrc.2017.03.043

13. Li X, Yang L, Chen LL. The biogenesis, functions, and challenges of circular RNAs. Mol Cell. (2018) 71:428-42. doi: 10.1016/j.molcel.2018.06.034

14. Yin J, Hu T, Xu L, Li P, Li M, Ye Y, et al. Circular RNA expression profile in peripheral blood mono-nuclear cells from Crohn disease patients. Medicine (Baltimore). (2019) 98:e16072. doi: 10.1097/MD.0000000000016072

15. Ye Y, Zhang L, Hu T, Yin J, Xu L, Pang Z, et al. CircRNA_103765 acts as a pro-inflammatory factor via sponging miR-30 family in Crohn's disease. Sci Rep. (2021) 11:565. doi: 10.1038/s41598-020-80663-w

16. Qiao YQ, Cai CW, Shen J, Zheng Q, Ran ZH. Circular RNA expression alterations in colon tissues of Crohn's disease patients. Mol Med Rep. (2019) 19:4500-6. doi: 10.3892/mmr.2019.10070

17. Giammanco A, Blanc V, Montenegro G, Klos C, Xie Y, Kennedy S, et al. Intestinal epithelial HuR modulates distinct pathways of proliferation and apoptosis and attenuates small intestinal and colonic tumor development. Cancer Res. (2014) 74:5322-35. doi: 10.1158/0008-5472.CAN-14-0726

18. Pott J, Kabat AM, Maloy KJ. Intestinal epithelial cell autophagy is required to protect against TNF-induced apoptosis during chronic colitis in mice. Cell Host Microbe. (2018) 23:191-202. doi: 10.1016/j.chom.2017.12.017

19. Holdt LM, Stahringer A, Sass K, Pichler G, Kulak NA, Wilfert W, et al. Circular non-coding RNA ANRIL modulates ribosomal RNA maturation and atherosclerosis in humans. Nat Commun. (2016) 7:12429. doi: 10.1038/ncomms12429

20. Holdt LM, Hoffmann S, Sass K, Langenberger D, Scholz M, Krohn K, et al. Alu elements in ANRIL non-coding RNA at chromosome 9p21 modulate 
atherogenic cell functions through trans-regulation of gene networks. PLoS Genet. (2013) 9:e1003588. doi: 10.1371/journal.pgen.1003588

21. Rankin CR, Lokhandwala ZA, Huang R, Pekow J, Pothoulakis C, Padua D. Linear and circular CDKN2B-AS1 expression is associated with inflammatory bowel disease and participates in intestinal barrier formation. Life Sci. (2019) 231:116571. doi: 10.1016/j.lfs.2019.116571

22. Fiorentino DF, Bond MW, Mosmann TR. Two types of mouse T helper cell. IV. Th2 clones secrete a factor that inhibits cytokine production by Th1 clones. J Exp Med. (1989) 170: 2081-95. doi: 10.1084/jem.170. 6.2081

23. Glocker EO, Kotlarz D, Boztug K, Gertz EM, Schaffer AA, Noyan F, et al. Inflammatory bowel disease and mutations affecting the interleukin10 receptor. N Engl J Med. (2009) 361:2033-45. doi: 10.1056/NEJMoa 0907206

24. Glocker EO, Frede N, Perro M, Sebire N, Elawad M, Shah $\mathrm{N}$, et al. Infant colitis-it's in the genes. Lancet. (2010) 376:1272. doi: 10.1016/S0140-6736(10)61008-2

25. Shouval DS, Ouahed J, Biswas A, Goettel JA, Horwitz BH, Klein C, et al. Interleukin 10 receptor signaling: master regulator of intestinal mucosal homeostasis in mice and humans. Adv Immunol. (2014) 122:177-210. doi: 10.1016/B978-0-12-800267-4.00005-5

26. Wolk K, Sabat R. Interleukin-22: A novel T- and NK-cell derived cytokine that regulates the biology of tissue cells. Cytokine Growth Factor Rev. (2006) 17:367-80. doi: 10.1016/j.cytogfr.2006.09.001

27. Franke A, Balschun T, Karlsen TH, Sventoraityte J, Nikolaus S, Mayr $\mathrm{G}$, et al. Sequence variants in IL10, ARPC2 and multiple other loci contribute to ulcerative colitis susceptibility. Nat Genet. (2008) 40:1319-23. doi: $10.1038 /$ ng.221

28. Nakamura K, Kitani A, Strober W. Cell contact-dependent immunosuppression by $\mathrm{CD} 4(+) \mathrm{CD} 25(+)$ regulatory $\mathrm{T}$ cells is mediated by cell surface-bound transforming growth factor beta. J Exp Med. (2001) 194:629-44. doi: 10.1084/jem.194.5.629

29. Das J, Ren G, Zhang L, Roberts AI, Zhao X, Bothwell AL, et al. Transforming growth factor beta is dispensable for the molecular orchestration of Th17 cell differentiation. J Exp Med. (2009) 206:2407-16. doi: 10.1084/jem.20082286

30. Ghoreschi K, Laurence A, Yang XP, Tato CM, McGeachy MJ, Konkel JE, et al. Generation of pathogenic $\mathrm{T}(\mathrm{H}) 17$ cells in the absence of TGF-beta signalling. Nature. (2010) 467:967-71. doi: 10.1038/nature09447

31. Bettelli E, Carrier Y, Gao W, Korn T, Strom TB, Oukka M, et al. Reciprocal developmental pathways for the generation of pathogenic effector TH17 and regulatory T cells. Nature. (2006) 441:235-8. doi: 10.1038/nature04753

32. Hu W, Troutman TD, Edukulla R, Pasare C. Priming microenvironments dictate cytokine requirements for $\mathrm{T}$ helper 17 cell lineage commitment. Immunity. (2011) 35:1010-22. doi: 10.1016/j.immuni.2011.10.013

33. Korn T, Bettelli E, Gao W, Awasthi A, Jager A, Strom TB, et al. IL-21 initiates an alternative pathway to induce proinflammatory $\mathrm{T}(\mathrm{H}) 17$ cells. Nature. (2007) 448:484-7. doi: 10.1038/nature05970

34. Nurieva R, Yang XO, Martinez G, Zhang Y, Panopoulos AD, Ma L, et al. Essential autocrine regulation by IL-21 in the generation of inflammatory T cells. Nature. (2007) 448:480-3. doi: 10.1038/nature05969

35. Zhou L, Lopes JE, Chong MM, Ivanov II, Min R, Victora GD, et al. TGFbeta-induced Foxp3 inhibits $\mathrm{T}(\mathrm{H}) 17$ cell differentiation by antagonizing RORgammat function. Nature. (2008) 453:236-40. doi: 10.1038/nature06878

36. Mitsuyama K, Sata M, Rose-John S. Interleukin-6 trans-signaling in inflammatory bowel disease. Cytokine Growth Factor Rev. (2006) 17:451-61. doi: 10.1016/j.cytogfr.2006.09.003

37. Alangari A, Alsultan A, Adly N, Massaad MJ, Kiani IS, Aljebreen A, et al. LPS-responsive beige-like anchor (LRBA) gene mutation in a family with inflammatory bowel disease and combined immunodeficiency. J Allergy Clin Immunol. (2012) 130:481-8. doi: 10.1016/j.jaci.2012.05.043

38. Magg T, Shcherbina A, Arslan D, Desai MM, Wall S, Mitsialis V, et al. CARMIL2 deficiency presenting as very early onset inflammatory bowel disease. Inflamm Bowel Dis. (2019) 25:1788-95. doi: 10.1093/ibd/izz103

39. Homer CR, Richmond AL, Rebert NA, Achkar JP, McDonald C. (2010). ATG16L1 and NOD2 interact in an autophagy-dependent antibacterial pathway implicated in Crohn's disease pathogenesis. Gastroenterol. (1641) 139:1630-41. doi: 10.1053/j.gastro.2010. 07.006
40. Li Q, Lee CH, Peters LA, Mastropaolo LA, Thoeni C, Elkadri A, et al. Variants in TRIM22 that affect NOD2 signaling are associated with veryearly-onset inflammatory bowel disease. Gastroenterol. (2016) 150:1196-207. doi: $10.1053 /$ j.gastro.2016.01.031

41. Torgerson TR., Ochs HD. Immune dysregulation, polyendocrinopathy, enteropathy, X-linked: Forkhead box protein three mutations and lack of regulatory T cells. J Allergy Clin Immunol. (2007) 120: 74452. doi: $10.1016 /$ j.jaci.2007.08.044

42. Latour S, Aguilar C. XIAP deficiency syndrome in humans. Semin Cell Dev Biol. (2015) 39:115-23. doi: 10.1016/j.semcdb.2015.01.015

43. Sechi LA, Gazouli M, Sieswerda LE, Molicotti P, Ahmed N, Ikonomopoulos J, et al. Relationship between Crohn's disease, infection with Mycobacterium avium subspecies paratuberculosis, and SLC11A1 gene polymorphisms in Sardinian patients. World $J$ Gastroenterol. (2006) 12:7161-4. doi: 10.3748/wjg.v12.i44.7161

44. Kuehn HS, Ouyang W, Lo B, Deenick EK, Niemela JE, Avery DT, et al. Immune dysregulation in human subjects with heterozygous germline mutations in CTLA4. Science. (2014) 345:1623-7. doi: 10.1126/science. 1255904

45. Zhou Q, Lee GS, Brady J, Datta S, Katan M, Sheikh A, et al. A hypermorphic missense mutation in PLCG2, encoding phospholipase Cgamma2, causes a dominantly inherited auto-inflammatory disease with immunodeficiency. Am J Hum Genet. (2012) 91:713-20. doi: 10.1016/j.ajhg.2012.08.006

46. Duerr RH, Taylor KD, Brant SR, Rioux JD, Silverberg MS, Daly MJ, et al. A genome-wide association study identifies IL23R as an inflammatory bowel disease gene. Science. (2006) 314:1461-3. doi: 10.1126/science.1135245

47. Xiao P, Zhang H, Zhang Y, Zheng M, Liu R, Zhao Y, et al. Phosphatase Shp2 exacerbates intestinal inflammation by disrupting macrophage responsiveness to interleukin-10. J Exp Med. (2019) 216:337-49. doi: 10.1084/jem.20181198

48. Banerjee S, Xie N, Cui H, Tan Z, Yang S, Icyuz M, et al. MicroRNA let-7c regulates macrophage polarization. J Immunol. (2013) 190:6542-9. doi: 10.4049/jimmunol.1202496

49. Chan AC, Kadlecek TA, Elder ME, Filipovich AH, Kuo WL, Iwashima $\mathrm{M}$, et al. ZAP-70 deficiency in an autosomal recessive form of severe combined immunodeficiency. Science. (1994) 264:1599-601. doi: $10.1126 /$ science. 8202713

50. Catucci M, Castiello MC, Pala F, Bosticardo M, Villa A. Autoimmunity in wiskott-aldrich syndrome: an unsolved enigma. Front Immunol. (2012) 3:209. doi: 10.3389/fimmu.2012.00209

51. Kelsen JR, Russo P, Sullivan KE. Early-onset inflammatory bowel disease. Immunol Allergy Clin North Am. (2019) 39:63-79. doi: 10.1016/j.iac.2018.08.008

52. Villa A, Notarangelo LD, Roifman CM. Omenn syndrome: inflammation in leaky severe combined immunodeficiency. J Allergy Clin Immunol. (2008) 122:1082-6. doi: 10.1016/j.jaci.2008.09.037

53. Punwani D, Wang H, Chan AY, Cowan MJ, Mallott J, Sunderam U, et al. Combined immunodeficiency due to MALT1 mutations, treated by hematopoietic cell transplantation. J Clin Immunol. (2015) 35:135-46. doi: 10.1007/s10875-014-0125-1

54. Sanal O, Jing H, Ozgur T, Ayvaz D, Strauss-Albee DM, ErsoyEvans S, et al. Additional diverse findings expand the clinical presentation of DOCK8 deficiency. J Clin Immunol. (2012) 32:698-708. doi: $10.1007 /$ s10875-012-9664-5

55. Levy J, Espanol-Boren T, Thomas C, Fischer A, Tovo P, Bordigoni P, et al. Clinical spectrum of X-linked hyper-IgM syndrome. J Pediatr. (1997) 131:47-54. doi: 10.1016/s0022-3476(97)70123-9

56. Quartier P, Bustamante J, Sanal O, Plebani A, Debre M, Deville A, et al. Clinical, immunologic and genetic analysis of 29 patients with autosomal recessive hyper-IgM syndrome due to Activation-Induced Cytidine Deaminase deficiency. Clin Immunol. (2004) 110:22-9. doi: 10.1016/j.clim.2003.10.007

57. Zimmer KP, Schumann H, Mecklenbeck S, Bruckner-Tuderman L. Esophageal stenosis in childhood: dystrophic epidermolysis bullosa without skin blistering due to collagen VII mutations. Gastroenterol. (2002) 122:220eroldoi: 10.1053/gast.2002.30428

58. Chalaris A, Gewiese J, Paliga K, Fleig L, Schneede A, Krieger K, et al. ADAM17-mediated shedding of the IL6R induces cleavage of the membrane 
stub by gamma-secretase. Biochim Biophys Acta. (2010) 1803:234-45. doi: 10.1016/j.bbamcr.2009.12.001

59. Karamchandani-Patel G, Hanson EP, Saltzman R, Kimball CE, Sorensen RU, Orange JS. Congenital alterations of NEMO glutamic acid 223 result in hypohidrotic ectodermal dysplasia and immunodeficiency with normal serum IgG levels. Ann Allergy Asthma Immunol. (2011) 107:50-6. doi: 10.1016/j.anai.2011.03.009

60. Sadler E, Klausegger A, Muss W, Deinsberger U, Pohla-Gubo G, Laimer $\mathrm{M}$, et al. Novel KIND1 gene mutation in Kindler syndrome with severe gastrointestinal tract involvement. Arch Dermatol. (2006) 142:1619-24. doi: 10.1001/archderm.142.12.1619

61. Avitzur Y, Guo C, Mastropaolo LA, Bahrami E, Chen H, Zhao Z, et al. Mutations in tetra-tricopeptide repeat domain 7A result in a severe form of very early onset inflammatory bowel disease. Gastroenterol. (2014) 146:102839. doi: 10.1053/j.gastro.2014.01.015

62. Zeissig S, Burgel N, Gunzel D, Richter J, Mankertz J, Wahnschaffe U, et al. Changes in expression and distribution of claudin 2, 5, and 8 lead to discontinuous tight junctions and barrier dysfunction in active Crohn's disease. Gut. (2007) 56:61-72. doi: 10.1136/gut.2006.094375

63. McGovern DP, Jones MR, Taylor KD, Marciante K, Yan X, Dubinsky M, et al. Fucosyltransferase 2 (FUT2) non-secretor status is associated with Crohn's disease. Hum Mol Genet. (2010) 19:3468-76. doi: 10.1093/hmg/ddq248

64. Vetrano S, Rescigno M, Cera MR, Correale C, Rumio C, Doni A, et al. Unique role of junctional adhesion molecule-a in maintaining mucosal homeostasis in inflammatory bowel disease. Gastroenterology. (2008) 135:173-84. doi: 10.1053/j.gastro.2008.04.002

65. Blaydon DC, Biancheri P, Di WL, Plagnol V, Cabral RM, Brooke MA, et al. Inflammatory skin and bowel disease linked to ADAM17 deletion. $N$ Engl J Med. (2011) 365:1502-8. doi: 10.1056/NEJMoa1100721

66. Ussar S, Moser M, Widmaier M, Rognoni E, Harrer C, GenzelBoroviczeny $\mathrm{O}$, et al. Loss of Kindlin-1 causes skin atrophy and lethal neonatal intestinal epithelial dysfunction. PLoS Genet. (2008) 4:e1000289. doi: 10.1371/journal.pgen.1000289

67. Fiskerstrand T, Arshad N, Haukanes BI, Tronstad RR, Pham KD, Johansson $\mathrm{S}$, et al. Familial diarrhea syndrome caused by an activating GUCY2C mutation. N Engl J Med. (2012) 366:1586-95. doi: 10.1056/NEJMoa1110132

68. Haberman Y, Tickle TL, Dexheimer PJ, Kim MO, Tang D, Karns R, et al. Pediatric Crohn disease patients exhibit specific ileal transcriptome and microbiome signature. J Clin Invest. (2014) 124:3617-33. doi: 10.1172/JCI75436

69. Olbjorn C, Cvancarova SM, Thiis-Evensen E, Nakstad B, Vatn MH, Jahnsen J, et al. Fecal microbiota profiles in treatment-naive pediatric inflammatory bowel disease - associations with disease phenotype, treatment, and outcome. Clin Exp Gastroenterol. (2019) 12:37-49. doi: 10.2147/CEG.S186235

70. Axelrad JE, Olen O, Askling J, Lebwohl B, Khalili H, Sachs MC, et al. Gastrointestinal infection increases odds of inflammatory bowel disease in a nationwide case-control study. Clin Gastroenterol Hepatol. (2019) 17:131122. doi: 10.1016/j.cgh.2018.09.034

71. Castano-Rodriguez N, Kaakoush NO, Lee WS, Mitchell HM. Dual role of Helicobacter and Campylobacter species in IBD: a systematic review and meta-analysis. Gut. (2017) 66:235-49. doi: 10.1136/gutjnl-2015-310545

72. Wu XW, Ji HZ, Yang MF, Wu L, Wang FY. Helicobacter pylori infection and inflammatory bowel disease in Asians: a meta-analysis. World $J$ Gastroenterol. (2015) 21:4750-6. doi: 10.3748/wjg.v21.i15.4750

73. Kolho KL, Klemola P, Simonen-Tikka ML, Ollonen ML, Roivainen M. Enteric viral pathogens in children with inflammatory bowel disease. J Med Virol. (2012) 84:345-7. doi: 10.1002/jmv.23193

74. Treem WR, Ahsan N, Shoup M, Hyams JS. Fecal short-chain fatty acids in children with inflammatory bowel disease. J Pediatr Gastroenterol Nutr. (1994) 18:159-64. doi: 10.1097/00005176-19940200000007

75. Bjerrum JT, Wang Y, Hao F, Coskun M, Ludwig C, Gunther U, et al. Metabonomics of human fecal extracts characterize ulcerative colitis, Crohn's disease and healthy individuals. Metabolomics. (2015) 11:122-33. doi: 10.1007/s11306-014-0677-3

76. Duboc H, Rajca S, Rainteau D, Benarous D, Maubert MA, Quervain E, et al. Connecting dysbiosis, bile-acid dysmetabolism, and gut inflammation in inflammatory bowel diseases. Gut. (2013) 62:531-9. doi: 10.1136/gutjnl-2012-302578

77. Canova C, Ludvigsson JF, Di Domenicantonio R, Zanier L, Barbiellini AC, Zingone F. Perinatal and antibiotic exposures and the risk of developing childhood-onset inflammatory bowel disease: a nested case-control study based on a population-based birth cohort. Int J Environ Res Public Health. (2020) 17:2409. doi: 10.3390/ijerph17072409

78. Hyams J, Crandall W, Kugathasan S, Griffiths A, Olson A, Johanns J, et al. Induction and maintenance infliximab therapy for the treatment of moderate-to-severe Crohn's disease in children. Gastroenterol. (2007) 132: 863-73. doi: 10.1053/j.gastro.2006.12.003

79. Hyams JS, Lerer T, Griffiths A, Pfefferkorn M, Stephens M, Evans J, et al. Outcome following infliximab therapy in children with ulcerative colitis. Am J Gastroenterol. (2010) 105:1430-430doi: 10.1038/ajg.2009.759

80. Takeuchi I, Kaburaki Y, Arai K, Shimizu H, Hirano Y, Nagata S, et al. Infliximab for very early-onset inflammatory bowel disease: a tertiary center experience in Japan. J Gastroenterol Hepatol. (2020) 35:593terol doi: 10.1111/jgh.14836

81. Gisbert JP, Marin AC, McNicholl AG, Chaparro M. Systematic review with meta-analysis: the efficacy of a second anti-TNF in patients with inflammatory bowel disease whose previous anti-TNF treatment has failed. Aliment Pharmacol Ther. (2015) 41:6131 Thedoi: 10.1111/apt.13083

82. Gisbert JP, Panes J. Loss of response and requirement of infliximab dose intensification in Crohn's disease: a review. Am J Gastroenterol. (2009) 104:760eroldoi: 10.1038/ajg.2008.88

83. Aboobacker S, Al Aboud AM. Infliximab-abda. In: StatPearls. Treasure island, FL: StatPearls Publishing (2021).

84. Fatima R, Bittar K, Aziz M. Infliximab. In: StatPearls. Treasure island, FL: StatPearls Publishing (2021).

85. Ellis CR, Azmat CE. Adalimumab. In: StatPearls. Treasure island, FL: StatPearls Publishing (2021).

86. Ng SC, Hilmi IN, Blake A, Bhayat F, Adsul S, Khan QR, et al. Low frequency of opportunistic infections in patients receiving vedolizumab in clinical trials and post-marketing setting. Inflamm Bowel Dis. (2018) 24:2431431:doi: 10.1093/ibd/izy153

87. Meserve J, Aniwan S, Koliani-Pace JL, Shashi P, Weiss A, Faleck D, et al. Retrospective analysis of safety of vedolizumab in patients with inflammatory bowel diseases. Clin Gastroenterol Hepatol. (2019) 17:1533533:doi: 10.1016/j.cgh.2018.09.035

88. Fabiszewska S, Derda E, Szymanska E, Osiecki M, Kierkus J. Safety and effectiveness of vedolizumab for the treatment of pediatric patients with very early onset inflammatory bowel diseases. J Clin Med. (2021). 10:2997. doi: 10.3390/jcm10132997

89. Conrad MA, Stein RE, Maxwell EC, Albenberg L, Baldassano $\mathrm{RN}$, Dawany $\mathrm{N}$, et al. Vedolizumab therapy in severe pediatric inflammatory bowel disease. Inflamm Bowel Dis. (2016) 22:2425425:doi: 10.1097/MIB.0000000000000918

90. Singh N, Rabizadeh S, Jossen J, Pittman N, Check M, Hashemi $\mathrm{G}$, et al. Multi-Center experience of vedolizumab effectiveness in pediatric inflammatory bowel disease. Inflamm Bowel Dis. (2016) 22:2121121doi: 10.1097/MIB.0000000000000865

91. Chavannes M, Martinez-Vinson C, Hart L, Kaniki N, Chao CY, Lawrence S, et al. Management of paediatric patients with medically refractory crohn's disease using ustekinumab: a multi-centred cohort study. J Crohns Colitis. (2019) 13:578olitidoi: 10.1093/ecco-jcc/jjy206

92. Dhaliwal J, McKay HE, Deslandres C, Debruyn J, Wine E, Wu A, et al. 1year outcomes with ustekinumab therapy in infliximab-refractory paediatric ulcerative colitis: a multicentre prospective study. Aliment Pharmacol Ther. (2021) 53:1300-300doi: 10.1111/apt.16388

93. Dayan JR, Dolinger M, Benkov K, Dunkin D, Jossen J, Lai J, et al. Real world experience with ustekinumab in children and young adults at a tertiary care pediatric inflammatory bowel disease center. $J$ Pediatr Gastroenterol Nutr. (2019) 69:61-7. doi: 10.1097/MPG.00000000000 02362

94. Bishop C, Simon H, Suskind D, Lee D, Wahbeh G. Ustekinumab in pediatric crohn disease patients. J Pediatr Gastroenterol Nutr. (2016) 63:348-51. doi: 10.1097/MPG.0000000000001146 
95. Cameron FL, Garrick V, Russell RK. Ustekinumab in treatment of refractory paediatric crohn disease. J Pediatr Gastroenterol Nutr. (2016) 62:e30. doi: 10.1097/MPG.0000000000000608

96. Kim FS, Patel PV, Stekol E, Ali S, Hamandi H, Heyman MB, et al. Experience using ustekinumab in pediatric patients with medically refractory crohn disease. J Pediatr Gastroenterol Nutr. (2021) 73:610-4. doi: 10.1097/MPG.0000000000003230

97. Haider M, Lashner B. Dual targeted therapy for the management of inflammatory bowel disease. J Clin Gastroenterol. (2021) 55:661-6. doi: 10.1097/MCG.0000000000001583

98. Dolinger MT, Spencer EA, Lai J, Dunkin D, Dubinsky MC. Dual biologic and small molecule therapy for the treatment of refractory pediatric inflammatory bowel disease. Inflamm Bowel Dis. (2021) 27:1210-4. doi: 10.1093/ibd/izaa277

99. Olbjorn C, Rove JB, Jahnsen J. Combination of biological agents in moderate to severe pediatric inflammatory bowel disease: a case series and review of the literature. Paediatr Drugs. (2020) 22:40916.doi: 10.1007/s40272-020-00396-1

100. Rudra S, Shaul E, Conrad MA, Patel T, Moore A, Dawany N, et al. Ruxolitinib: targeted approach for treatment of autoinflammatory very early onset inflammatory bowel disease. Clin Gastroenterol Hepatol. (2021) 21:S1542-3565. doi: 10.1016/j.cgh.2021.07.040

101. Connors J, Basseri S, Grant A, Giffin N, Mahdi G, Noble A, et al. Exclusive enteral nutrition therapy in paediatric crohn's disease results in long-term avoidance of corticosteroids: results of a propensity-score matched cohort analysis. J Crohns Colitis. (2017) 11:1063-70. doi: 10.1093/ecco-jcc/jjx060

102. Diederen K, Li JV, Donachie GE, de Meij TG, de Waart DR, Hakvoort T, et al. Exclusive enteral nutrition mediates gut microbial and metabolic changes that are associated with remission in children with Crohn's disease. Sci Rep. (2020) 10:18879. doi: 10.1038/s41598-020-75306-Z

103. Hugot JP, Chamaillard M, Zouali H, Lesage S, Cezard JP, Belaiche J, et al. Association of NOD2 leucine-rich repeat variants with susceptibility to Crohn's disease. Nature. (2001) 411:599-63. doi: 10.1038/35079107

104. Kucuk ZY, Bleesing JJ, Marsh R, Zhang K, Davies S, Filipovich AH. A challenging undertaking: stem cell transplantation for immune dysregulation, polyendocrinopathy, enteropathy, X-linked (IPEX) syndrome. J Allergy Clin Immunol. (2016) 137:953-5. doi: 10.1016/j.jaci.2015.09.030

105. Engelhardt KR, Shah N, Faizura-Yeop I, Kocacik UD, Frede N, Muise AM, et al. Clinical outcome in IL-10- and IL-10 receptor-deficient patients with or without hematopoietic stem cell transplantation. J Allergy Clin Immunol. (2013) 131:825-30. doi: 10.1016/j.jaci.2012.09.025

106. Kotlarz D, Beier R, Murugan D, Diestelhorst J, Jensen O, Boztug K, et al. Loss of interleukin-10 signaling and infantile inflammatory bowel disease: implications for diagnosis and therapy. Gastroenterol. (2012) 143:347-55. doi: 10.1053/j.gastro.2012.04.045

107. Murugan D, Albert MH, Langemeier J, Bohne J, Puchalka J, Jarvinen $\mathrm{PM}$, et al. Very early onset inflammatory bowel disease associated with aberrant trafficking of IL-10R1 and cure by $\mathrm{T}$ cell replete haploidentical bone marrow transplantation. J Clin Immunol. (2014) 34:3319. doi: 10.1007/s10875-014-9992-8

108. Tsuma Y, Imamura T, Ichise E, Sakamoto K, Ouchi K, Osone S, et al. Successful treatment of idiopathic colitis related to XIAP deficiency with allo-HSCT using reduced-intensity conditioning. Pediatr Transplant. (2015) 19:E25-8. doi: 10.1111/petr.12405

109. Lekbua A, Ouahed J, O'Connell AE, Kahn SA, Goldsmith JD, Imamura T, et al. Risk-factors associated with poor outcomes in VEO-IBD secondary to XIAP deficiency: A case report and literature review. J Pediatr Gastroenterol Nutr. (2019) 69:e13-8. doi: 10.1097/MPG.0000000000002297

110. Chen R, Giliani S, Lanzi G, Mias GI, Lonardi S, Dobbs K, et al. Wholeexome sequencing identifies tetratricopeptide repeat domain 7A (TTC7A) mutations for combined immunodeficiency with intestinal atresias. J Allergy Clin Immunol. (2013) 132:656-64. doi: 10.1016/j.jaci.2013.06.013

111. Klemann C, Pannicke U, Morris-Rosendahl DJ, Vlantis K, Rizzi M, Uhlig $\mathrm{H}$, et al. Transplantation from a symptomatic carrier sister restores host defenses but does not prevent colitis in NEMO deficiency. Clin Immunol. (2016) 164:52-6. doi: 10.1016/j.clim.2016.01.010

112. Lourenco R, Azevedo S, Lopes AI. Surgery in pediatric crohn disease: Case series from a single tertiary referral center. GE Port J Gastroenterol. (2016) 23:191-6. doi: 10.1016/j.jpge.2016.03.007

113. Abraham BP, Mehta S, El-Serag HB. Natural history of pediatric-onset inflammatory bowel disease: a systematic review. J Clin Gastroenterol. (2012) 46:581-9. doi: 10.1097/MCG.0b013e318247c32f

114. Pini-Prato A, Faticato MG, Barabino A, Arrigo S, Gandullia P, Mazzola C, et al. Minimally invasive surgery for paediatric inflammatory bowel disease: personal experience and literature review. World J Gastroenterol. (2015) 21:11312-20. doi: 10.3748/wjg.v21.i40.11312

115. Paramsothy S, Kamm MA, Kaakoush NO, Walsh AJ, van den Bogaerde J, Samuel D, et al. Multidonor intensive faecal microbiota transplantation for active ulcerative colitis: A randomised placebocontrolled trial. Lancet. (2017) 389:1218-28. doi: 10.1016/S0140-6736(17)3 0182-4

116. Rossen NG, Fuentes S, van der Spek MJ, Tijssen JG, Hartman JH, Duflou A, et al. Findings from a randomized controlled trial of fecal transplantation for patients with ulcerative colitis. Gastroenterol. (2015) 1108. doi: 10.1053/j.gastro.2015.03.045

117. Hourigan SK, Oliva-Hemker M. Fecal microbiota transplantation in children: a brief review. Pediatr Res. (2016) 80: 2-6. doi: 10.1038/pr.2016.48

Conflict of Interest: The authors declare that the research was conducted in the absence of any commercial or financial relationships that could be construed as a potential conflict of interest.

Publisher's Note: All claims expressed in this article are solely those of the authors and do not necessarily represent those of their affiliated organizations, or those of the publisher, the editors and the reviewers. Any product that may be evaluated in this article, or claim that may be made by its manufacturer, is not guaranteed or endorsed by the publisher.

Copyright (c) $2022 \mathrm{Li}$, Zhang and Dai. This is an open-access article distributed under the terms of the Creative Commons Attribution License (CC BY). The use, distribution or reproduction in other forums is permitted, provided the original author(s) and the copyright owner(s) are credited and that the original publication in this journal is cited, in accordance with accepted academic practice. No use, distribution or reproduction is permitted which does not comply with these terms. 